\section{A critical comparison of welfare states and their relevance to people with an intellectual disability}

\section{Linda de Chenu}

University of Hertforshire, UK

\section{Dag Dæhlen}

Oslo and Akershus University College of Applied Sciences, Norway

\section{Jude Tah}

Stockholm University, Sweden

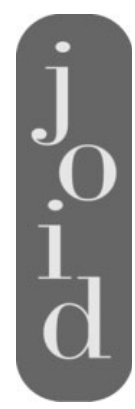

Journal of Intellectual Disabilities 2016, Vol. 20(4) 397-415

(C) The Author(s) 2016

Reprints and permission: sagepub.co.uk/journalsPermissions.nav DOI: 10.1 I77/I7446295/56246/3 jid.sagepub.com

(SAGE

Date accepted: 09 November 2015

\begin{abstract}
This article compares the welfare services for adults with an intellectual disability in three European countries: England, Norway and Sweden. The purpose of the comparison is to develop an understanding of the welfare state and institutional contexts of the country-specific policies and to develop a critical analysis through a comparative method based on selected secondary literature. Typological frameworks of European welfare states are applied as analytic frameworks to enable comparison between the countries. It is argued that there are international policy developments but these are shaped at a national level by different types of welfare states and histories. Through a comparison of similarities and differences, the article suggests that international policy ideas that impact on the lives of people with intellectual disabilities are mediated by different types of welfare states and institutions.
\end{abstract}

\title{
Keywords
}

definitions of disability, intellectual disability, welfare state, environmental turn, work activation, social care budgets 


\section{Introduction}

The themes of this article were developed during a 3-year Erasmus Intensive Programme, which aimed to enable future practitioners in the field of intellectual disabilities to compare the welfare contexts of different countries which influence the lives of people with intellectual disabilities. The authors have developed this comparison using a purposive sample of Norway, Sweden and England (Neuman, 2006).

The value of comparison is that 'making a comparison between one thing and another is an important way of learning' (Stafford et al., 2012: 56). A comparative study can highlight the similarities and differences between the policies in different countries and explanations of their causes can be suggested (Mackie and Marsh,1995). Moreover 'comparing what happens' when different countries introduce new policies enables the identification of issues that would have been missed without comparison (Peters, 1998; Mackie and Marsh, 1995). Here in order to move beyond description, the use of typologies of welfare states helps to categorize the descriptive accounts and facilitate comparison and further research (Cousins, 2005).

The local or national terminologies of disability (Jenkins, 1998) and intellectual disability are introduced for each country, followed by a discussion of firstly the national welfare states and their welfare payments and secondly social care services. The comparison includes discussion of how each country 'mediates' the recent international policy developments (Yeates, 2008) of work activation (Lodemel and Moreira, 2014) and privatization (Peterson, 2011).

The institutional features of the countries are an important context and all three countries are parliamentary democracies. The Scandinavian governments are designed to resolve conflict and the 'predominant style of policy-making is seen as concertative and deliberative' (Elder et al., 1982: 180) and is described as 'corporatist' as interests are systematically included in policymaking. From a comparative perspective, Pierson (1994: 33) argues that the English government has a strong control over the policy-making process which enables politicians to introduce policies incrementally, and restructure institutions designed to achieve welfare economies without opposition'. In particular, Scandinavian local government has a 'relative autonomy', which gives independence to local authorities (LAs) within a framework of power and duties, whereas an 'agency' model describes English local government as mainly agencies for central government policies (Stoker, 1991).

Since World War Two (WW2), the deinstitutionalization of people with intellectual disability emerged internationally in response to the international rejection of the incarceration of peoples. Different theories or models of disability emerged, some of which maintain a modernist 'othering' of people with disabilities in contrast to postmodern theory that addresses the complexity and identity issues of disability. Carling-Jenkins (2014) describes the medical model, the economic model, the normalization and social role valorization (SRV) model, the British social model and the psychosocial International Classification of Function and Disability's (ICF) model as modern. She describes both the Scandinavian Gap model in which disability is seen as a consequence of a gap between individual and environmental factors and theory based on identity and complexity as postmodern and liberating people with disabilities from 'otherness'. This article suggests which general models identified by Carling-Jenkins (2014) are influential in the different countries.

Internationally, the terminology used and their understanding have changed with time. The WHO-ICF (2001), described by Carling-Jenkins as a psychosocial model, conceptualized disability as a product of human functioning and contextual and environmental factors. In this sense, therefore, environmental and contextual factors became important in how support is organized and 
provided to persons with intellectual disability. From an international perspective, the term intellectual disability as defined by the American Association of Intellectual Developmental Disabilities (AAIDD, no date) and, the American Psychiatric Association (2013) in The Diagnostic and Statistical Manual of Mental Disorders V align with the terminology and conceptualization used by WHO in the ICF 2001. However, the International Classification of Diseases (ICD)-10 (WHO, 1992) is a classification system used for diagnosis and administrative welfare assessments in all three countries, which uses outdated medical model terms but is being reviewed for ICD-11.

These conceptualizations of intellectual disability, in terms not only of mental ability but also adaptive functioning, are crucial as emphasis is not solely placed on the inability of the individual but also the adaptive functioning and learning that is age-appropriate and meets the standards of culture-appropriate demands of daily life (Carulla et al., 2011).

In response to the disability movement and changing understandings of disability the UN Convention on Human Rights in 1948, the 1971 United Nations Declaration on the Rights of Mentally Retarded Persons and then the 2006 UN Convention on the Rights of Persons with Disabilities (CRPD) have developed rights for people with an intellectual disability. Article 19 of the CRPD concerns living independently and being included in the community and Article 28 concerns an adequate standard of living and social protection. All three countries have ratified the Convention and Sweden and England have ratified the Optional Protocol for complaints which is currently under consideration in Norway (UN, 2013).

The article discusses the types of welfare payments available to people with ID which are relevant to the CRPD Article 28. The classification of welfare states introduced by EspingAndersen (1990) based on welfare or 'transfer' payments suggests three main types of Welfare State Regimes which are applied to the three countries. These are the liberal welfare state in which state involvement is low and benefits are low and means tested. The corporativist-statist regime, where benefits are connected to existing social and economic status, where both the state and organizations play an important role. Thirdly, the social democratic welfare state combines high state involvement with universal rights to benefits in which the state organizes social insurance, which is financed through taxation. Esping-Andersen (2014) argues that the Welfare State is in its own right a system of stratification, which may increase or reduce inequalities. The recent international spread of 'work activation' policy (Moreira and Loedemel, 2014) has introduced 'conditionality' into welfare payments and the effects on people with intellectual disabilities in the different welfare states are compared.

Social services are central to the CRPD Article 19 and a second welfare state typology analyses the contribution made to social services by four different sectors: the informal, voluntary nonprofit, state and for-profit sectors and presents a model of four types of social service provision (Antonnen and Sipila, 1996 cited in Munday, 2003). The Scandinavian model of public provision of services is based on the principle of universalism, the family care model has limited state provision, the means tested model of the United Kingdom, where the state withdraws from direct service provision and targets services on the most dependent service users, and the northern European subsidiarity model, where services are provided mainly by non-governmental organizations. The recent influence of the international 'reform' movement on welfare states, which seeks to create markets in public services and open up social services to privatization, are also compared.

To enable comparison, secondary literature and country-specific statistics have been selected to describe country characteristics. Emerson et al. (2013) note that statistics within countries are not comparable and similarly we note that there are too many differences in their collation for statistics 
to be directly comparable between countries (Ulmestig, 2013). In this article, the focus is on the description and comparison of service characteristics and trends relevant to adults with intellectual disabilities.

\section{Norway: Introduction}

In the mid-60s, the Norwegian government started to use the term 'funksjonshemming', instead of the previous term 'handicap', which can be loosely translated as 'functionally inhibited', and disability is seen as a gap between individual functional ability and environmental factors, often called 'the GAP model' in Norway (Tøssebro, 2010). Reducing this gap may lead to efforts to increase individual functional capability, decrease environmental demands and barriers, or both (Hedlund, 2009). The term funksjonshemming is often broken down into 'funksjonsnedsettelse', which covers a reduction in an individual's functional ability, and 'funksjonshemmende forhold', which covers environmental barriers (Manneråk, 2001) After 1966, the term 'psykisk utviklingshemming' or 'utviklingshemming' became the general concepts in use for intellectual disability. The closest English term would be developmental disability.

\section{Norway: Welfare state and welfare benefits}

The Norwegian welfare state is classified as a Social Democratic welfare state (Esping-Andersen, 1990) because benefits and services are largely provided by the state through the municipal LA and are largely financed through taxes and through compulsory membership of the national social insurance scheme. Its oil industry and government petroleum fund has largely allowed Norway to escape the austerity measures seen elsewhere since 2008.

The Norwegian welfare state is universal, though access to certain benefits and services are connected to specific social or medical eligibility criteria so that municipal professionals and officials have a powerful role as gatekeepers (Kuhnle and Kildal, 2005). Frame laws govern welfare benefits and services normalize entitlement as there are few laws regulating specific groups.

The Norwegian welfare state redistributes wealth, and though benefits like pensions are linked to previous income, the minimum levels of support are still fairly high, though since 1991 some of these groups have been subject to workfare or a duty to work with economic sanctions. In 2006, the Norwegian Labour and Welfare Administration (NAV) was established to facilitate cooperation between state and municipal levels for an activation policy (Gubrium et al., 2014). Local NAV offices are placed in the municipalities, and the staff have mainly university or college education in relevant fields, to carry out holistic assessments and plans (NAV, 2014). However, people with intellectual disability very rarely enter the regular workforce and are instead largely de-commodified through income support provisions (Olsen, 2009).

The most important income support provision for disabled adults in Norway is the disability pension and entitlement is based on the loss of working capacity at or above $50 \%$, due to illness, injury or disability. Thus, a diagnosis in itself does not give entitlement but the impact on a person's working capacity (Hatland, 2010). It can be described as a typical universal benefit, which awards the same payment to all recipients regardless of disability. Additional costs connected to specific disabilities administered by NAV outside the general disability pension (NAV, 2015).

The average income after tax for a person with disability pension is approximately $80 \%$ of the national average. Based on nationwide income statistics from every private household collected by Statistics Norway, research has found that their chances of having permanently low income as 
defined by the European Union is about the same as for the population in general (Epland, 2011). Disability pension has been changed to disability benefits as of 1 January 2015. The government has claimed this change should have little negative impact on income, but the results of this reform are not yet clear (Regjeringen, 2014). There are housing benefits, state-subsidized loan schemes and assistance available from municipalities to help people with lower income finance their housing (Norge Barne-og, 2013).

\section{Norway: Welfare state and social services}

Up until the early-90s, people with intellectual disability commonly lived in specialist institutions, which were the responsibility of the county authorities. Deinstitutionalization was initiated in 1988 and responsibility for all services was moved from the county to the municipality during the period from 1991 to 1995 although the counties would still provide guidance, special health services and hospital care (Thomassen, 1989). People with intellectual disability were to receive the same services, from the same providers as the general population whilst living in their own homes.

Norway can be classified as a Scandinavian model of public provision of social services (Antonnen and Sipila, 1996, cited in Munday, 2003), which are mostly administered by the municipalities whilst the county provides specialized support and the voluntary and private sectors play a relatively small role. Based on data from Statistics Norway collected from the Norwegian municipalities, less than $1 \%$ of home nursing turnover was estimated to have been provided by the voluntary or private sector in 2010 (Godager et al., 2011). However, according to a survey among the municipalities done by the Norwegian Institute for Urban and Regional Research, the portion of municipalities using competitive tendering in home-based services has increased somewhat from $2 \%$ in 2004 to $7 \%$ in 2012 (Blåka et al., 2012).

Important home-based services available to adults with intellectual disabilities are practical assistance, home nursing and user-controlled personal assistance (Brevik, 2012). The extent of available services is determined by the municipality based on individual needs, as determined by healthcare or social workers, and are regulated by the Social Services Act (Norwegian Parliament, 2009) and the Health Care Act (Norwegian Parliament, 2011). Almost all the assistance and care provided at home is carried out by municipal home services, with very few private sector providers. However, in some municipalities, users can choose private sector providers, but access to services and the costs are handled by the municipality, though in $2012,8 \%$ of the municipalities allowed free choice of service provider (Gautun et al., 2013). Around $70 \%$ of those working in health and social care services had relevant education in this field in 2010 (Helse-og omsorgsdepartementet, 2010).

Norway has seen an increased focus on user participation and control over the services provided (Norge Helse-og, 2006,2013), though research indicates that individual care plans are poorly developed (Næss and Grue, 2012; Norge Barne-og, 2013). Only 1\% of users received services via user-controlled personal assistance in 2013. However, in 2015, this became a right rather than an option for municipalities to offer so this may change (Mørk et al., 2014).

People with intellectual disability commonly live in shared housing rented from the municipality (Brevik and Høyland, 2007; Tøssebro and Lundeby, 2002).

In 2011, the Norwegian University of Science and Technology published the results of a large survey on living conditions and services for people with intellectual disabilities. Data were collected from municipal workers, guardians/next of kin, as well as qualitative interviews with people with intellectual disabilities (Söderström and Tøssebro, 2011). On average, people moving into 
group homes after the year 2000 live with seven other people, having their own flat but sharing some common areas between them. Twenty-seven percent lived in group homes with people with other disabilities, most commonly psychological disabilities or the elderly. This might indicate that housing is becoming more centralized and is moving towards what might be called 'miniinstitutions', especially in larger municipalities (Söderström and Tøssebro, 2011).

Few people with intellectual disability participate in the regular workforce. Municipal daytime services have moved away from production towards more general activities since the 1990s. In $2010,22 \%$ of adults with intellectual disability participated in state-organized job creation or work programmes or the regular workforce. Sixty percent had their day activities at in municipal day centres, $17 \%$ of these involved mainly in production. Three percent participated in adult education, whilst $16 \%$ had no day activities of any kind, a rise from 3\% in 1989 (Söderström and Tøssebro, 2011).

\section{Sweden: Introduction}

The medical perspective dominated the understanding of disability in Sweden until the1970s when the environmental-related view of disability gained prominence (Socialstyrelsen, 2006). Today disability is viewed as a reduction in functional ability that poses a limitation to the individual's functioning in relation to the demand of the environment (Socialstyrelsen, no date). Sweden uses funktionsnedsättning and funkstionshinder to define disability, a loose translation will be reduction for functional ability and functional impairment respectively. A reduction of functional ability is defined as a reduction in the physical, mental and intellectual functioning. Whilst functional impairment is defined as a limitation due to a disability in relation to the environment (Socialstyrelesen, 2014).

Currently, the Swedish disability policy From patient to citizen. A national action plan for disability policy (Ministry of Health and Social Affairs, 2000) is based on inclusive citizenship; it emphasizes equal value and equal rights, narrowing the gap between people with disabilities and people without disabilities and covers the whole of society enabling full participation in community life.

\section{Sweden: Welfare state and welfare benefits}

Similarly to Norway, Sweden is classified as a social democratic welfare state (Esping-Andersen, 1990). The state organizes social insurance, which is financed through taxation. Urban and Amark (2001) write that since the 1960s, the Swedish social security system has combined universalism, with social rights and income benefits available to all inhabitants with selective access to some benefits and services based on social, medical or other conditions.

The policy aim is for people with disabilities to maintain a modest but secure standard of living through income and other support services (Ratzka, 2003). Disability benefits are the most significant source of income for people with disabilities in Sweden. People with disabilities between the ages of 30 and 64 and a reduced work ability of at least a quarter are eligible for disability benefits. Young people with disabilities between the ages of 19 and 30 are eligible for activity compensation and before 19 years are eligible for care support allowance (Forsakringskassan, 2014).

Jönsson et al. (2010) affirm that disability insurance is one of Sweden's most important income security programmes. In the late 1990s, Sweden introduced work activation and conditionality to welfare benefits through 'Activity Guarantees', but these were not applicable to claimants with 
'social problems' and were to be implemented at the discretion of the municipalities (Kananen, 2014).

Compared to other industrialized countries, the share of Swedish population receiving support from the disability insurance programme is quite large (Gruber and Wise, 2010). As in Norway, should one compare the income level of people with disabilities to that of the general population, it is still relatively lower. Reports on household income presented by Statistics Sweden showed people with mental disabilities had about 30\% lower household income in both 2005/2006 as well as in 2009 compared with the general population in Sweden. Furthermore, the reports indicate that average income derived from workforce participation for people with mental disabilities was less than half of that of the general population (Statistik centralbyrån, 2009). Furthermore, figures from the National Health and Welfare board show that people with disabilities in general had about $20 \%$ lower individual income compared to the general population (Socialstyrelsen, 2010).

\section{Sweden: Welfare state and social care}

Until the mid-1970s, institutional care dominated, yet there were a limited number of communitybased services (Ericsson, 1999). The influence of normalization in the 1970s led to the initiation of community services for people with a disability that were available to all. This process culminated with the final dissolution of residential institutions in 1997 and the closing down of all institutions from 31 December 1999 (Race, 2007). Mansell et al. (2004) reported that Sweden was one of the few countries to successfully deinstitutionalize.

Sweden in common with Norway demonstrates a Scandinavian model of public provision of social care (Antonnen and Sipila, 1996, cited in Munday, 2003), which is mostly administered by the municipalities, whilst the county provides specialized support. There is primarily a dual system of care provided by the municipality and the market (Socialstyrelsen, 2010). A new public management structure has seen the involvement of private enterprise in the provision of services in areas of schooling, health and disability care (Tideman, 2012). The privatization of social care provision since 1990 has resulted in significant increase in private care providers (Lindström and Josephine, 2003; Stolt et al., 2011). Although the municipalities are responsible for social care services, there is an increasing collaboration with the voluntary sector, for example The Swedish National Association for Persons with Intellectual Disability participates in the organization, provision and evaluation of services.

Tideman (2012) points out that factors such as the economic situation, political control of the council or municipality, the negotiation skills of the person with a disability as well as the tradition of providing care will influence the services provided across the different counties and municipalities. Social services are governed by a Frame law the Social Service Act (SoL) based on principles of human rights and equality which was adopted in 1982 (amended in 2001) and includes home assistance, mobility, advocacy, housing, leisure time and daytime services (Power et al., 2013; Socialdepartementet, 2001, Socialstyrelsen, 2009).

The individualization or personalization of support and the empowerment of people as purchasers was introduced by The Act Concerning Support and Service for Persons with Certain Functional Impairments (LSS) (Socialdepartementet, 1993a), which gives people with intellectual disabilities rights to 10 categories of additional special support and services including personal assistance (Power et al., 2013; Socialstyrelsen, 2009). Figures from 2009 from the National Board of Health and Welfare show that about 36,000 people with intellectual disabilities received support 
through LSS, corresponding to about $0.4 \%$ of the population and over 17,000 of these were children and youth and about 32,000 were adults under the age of 65 (Socialstyrelsen, 2009)

This system of direct payments to the user and the promotion of user's choice has extended private social care provision. However, this move towards privatisation is seen by many as contrary to the ideology of the Swedish 'people's home' in which public services support the creation of social equality (Blomqvist, 2004). On the other hand, the introduction of private actors and 'consumer choice' is seen as a way to empower users.

People with intellectual disabilities live primarily in small group accommodation in the community provided by the municipality. A summary of recent studies show that there is an increasing movement from smaller accommodation units with three to five persons to larger units These studies also indicate that the ability to choose or change accommodation is limited (Socialstyrelsen, 2011).

People with intellectual disabilities are generally 'outsiders' in the labour market. A significant and increasing majority participate in day activity centres (Socialstyrelsen, 2011) due to increasing demands in the labour market, non-prioritization of this category by the National employment agency and also higher requirements for employment by the public employment agency for people with disabilities.

\section{England: Introduction}

The English definition of intellectual disability has changed over time and the NHS and Community Care Act (DH, 1990) introduced the term 'learning disability' to replace 'mental handicap', this legislation introduced the care market and further 'privatization' of services. This term has also been adopted by the voluntary sector and the consolidating Equality Act (UK Parliament, 2010) and the policy 'Valuing People' (2001) which drew on ideas from normalization and SRV (Race, 2007). Also driven by new managerialism, these policies sought to develop and 'steer' personcentred care in the welfare market.

From the 1970s, the wider UK disability movement developed the 'social model of disability', which identified environmental factors as disabling and used the term 'disabled people'. From this perspective, the term 'learning disability' is oppressive, as it locates the causes of disability within the individuals condition rather than in the disabling social environment, a response has been to use the term 'learning difficulties' as a non-oppressive term (Boxall, 2002).

\section{England: Welfare state and welfare benefits}

The English welfare state is defined as a Liberal type by Esping-Andersen (1990) in which the levels of universal benefits and social insurance are modest. The emphasis is on market-based insurance and the use of means testing for social benefits and welfare is orientated to the dependent poor (Cochrane et al., 2001).

With the Liberal welfare state, the need for paid work and private savings are increased, and Esping-Andersen argues that the Liberal or Anglo Saxon model is the least de-commodifying and he emphasizes that 'entitlement rules are strict' and 'often associated with stigma (2014: 144). The highly centralized English income maintenance services are controlled by the central government Department of Work and Pensions (DWP) and delivered through its local offices. Wright (2011: 106) demonstrates that the DWP is 'driven by a cost cutting rationale, backed up by ideologically based calls to end welfare dependency'. Hence, the English type of welfare state differs from the 
Norwegian and Swedish social democratic type and welfare benefits are the province of central government not local government as in the Scandinavian countries.

This Liberal model is illustrated by the extent that the Welfare Reform Act (2012) introduces work activation and conditionality to people with disabilities so recommodifying their work. It also marketizes the delivery of assessment and work support to people with disabilities (Griggs et al., 2014) and has arguably depressed the levels of benefits and rendered people with intellectual disabilities vulnerable to receiving no benefits (Grover and Piggott, 2015). Although historically, people with disabilities have been seen as deserving the use of work activation can cast them as 'shirkers' who avoid paid work (Woodin, 2015). The policy of work activation was initially supported by the disability movement who saw access to the workplace as the means to empowerment (Grover and Piggott, 2015).

Hence, it appears that welfare reform (UK Department of Work and Pensions, 2012) will decrease the accessibility and scope of benefits for people with a disability (Beatty et al., 2013). The replacement of the previous Incapacity Benefit by the Employment and Support Allowance (ESA) for new claimants involves Work Capability Assessments (WCA) delivered by two private companies Atos and Capita (Kennedy, 2015) and people with disabilities are placed either in a 'support group' or 'work-related activity group' with lower benefits (Blow, 2015). In 2015, this benefit has been reduced to the same level as the general jobseeker allowance or unemployment benefit (Clark et al., 2015). Blow reports that people with intellectual disabilities have problems engaging with the WCA, and there is a lack of work-related support. Woodin (2015) reports that people with medium to more severe intellectual disabilities are often left 'parked' in the 'support group' with no help to develop daily activities as there is less chance of them achieving the outcome of paid work required for a company such as Atos or Capita to profit (Woodin, 2015).

Moreover $58 \%$ of sanctions (whereby benefits are initially reduced and then stopped altogether) have been imposed on people with mental health or intellectual disabilities. In addition, the Personal Independence Payment (PIP) is replacing the previous Disabled Living Allowance (DLA) and the aim is that 600,000 fewer people will claim than would have received DLA and expenditure will be $£ 2.5$ billion a year lower than previously due partly to austerity policies (Kennedy, 2015).

Long delays for decisions about PIP awards are having a negative effect (Mencap, 2014b) and people with milder intellectual disabilities may not be awarded PIP despite their additional needs which jeopardizes their independence (Mencap, 2012b). A Bedroom Tax has caused people in social housing to lose income if deemed to have too much space, and Mencap (2014a) has argued that people with intellectual disabilities need more bedroom space.

Recent research (Alzubaidi et al., 2013) compared income after housing costs of people with intellectual disabilities to median income in the United Kingdom. They found that in 2011/2012 of households with one or more adults with intellectual disability, $32 \%$ were below the median income compared to $21 \%$ of households where no one had an intellectual disability.

\section{England: Welfare state and social services}

The means tested model, Antonnen and Sipila (1996, cited in Munday, 2003), is found in England, where the state increasingly withdraws from the role of direct service provision and develops contracts with providers from the private and voluntary sectors, and targets services on 'problem cases'. This type also depends on informal support from the families of people with an intellectual disability. LA social care services are allocated through Fair Access to Care (FAC) (DH, 2002) and 
eligibility requires that applicants are at 'risk' (Race, 2007) and the level of risk can be raised following austerity measures and cuts to LA funding.

The austerity measures of the Coalition and Conservative governments since 2011 have meant that by 2012-2013 almost half the LAs had cut their social service budgets for people with intellectual disabilities by $£ 10$ million (Mencap, 2012a). It is important to emphasize that Emerson et al. (2013) have identified a disparity between the numbers of people with intellectual disability assessed by the central government DWP as receiving DLA in 2011 of 380,000 and information from LAs that approximately 140-150,000 adults received social services. This indicates that due to this institutional divide 'little is known about the health and well being' and social service needs of a 'hidden majority' of people with intellectual disabilities (2013: vi-vii).

The community care reforms (UK DH, 1990) introduced a market for social services and LAs were required to spend $85 \%$ of their budget in the Private, Voluntary and Independent (PVI) sectors. This established an 'economic model' (Carling-Jenkins, 2014) in which people with disabilities became 'commodities' for private companies to extract profit. Services were to be purchased directly by individual 'consumers' with the introduction of direct payments (DH, 1996) and the 'personalisation agenda' has further developed this process of the 'individualisation of provision' (Beadle-Brown et al., 2003: 106).

Williams questions the amount of real choice that is exercised by people with intellectual disabilities and also highlights the poor training of support workers (Williams, 2013: 159) The recent Care Bill (UK DH, 2014) expects that personal budgets will be used, for all residential, day and support services. Not only will service provision be largely in the private and independent sectors but the LA assessment for funds from 2014 is to be outsourced to the private sector (Schwehr, 2014). From $2009 / 10$ to $2010 / 11$ there was an $81 \%$ increase in adults with intellectual disabilities using direct payments or self directed support, the biggest increase was in self directed support for 'council services only' (Emerson et al, 2013: iv).

For day time activities $6.6 \%$ of people with intellectual disabilities were in some type of paid employment and of these most worked part time (Emerson et al, 2013: iv). The number of people with intellectual disabilities in day care services has decreased from 2005/06 by about $\%$ a year and 52,150 were using local authority funded day service 2010/11 (Emerson et al, 2013: iv).

An important indicator of the extent and type of community living is residential status and in $2010 / 11$ of the 138.995 adults with intellectual disability reported by LAs to be in some form of accommodation $29.6 \%$ were reported to be living with family or friend. Of the remainder $16.9 \%$ were living in registered care homes, $12.7 \%$ in supported group homes and $12.5 \%$ in some sort of tenancy, $1.7 \%$ in owner occupied, $0.9 \%$ in nursing homes, $0.8 \%$ in hospitals and $0.5 \%$ in sheltered housing (Emerson, 2013: iii). The most common form of residential care or $79 \%$ was in the independent (private) sector (Emerson, 2013: 67-68). The Winterbourne Review (DH, 2012) of a private hospital for people with intellectual disabilities, following their mistreatment, has highlighted the problems of regulating private providers as well as the high numbers of people still living in hospital institutions. The Health and Social Care Information Centre in partnership with the Care Quality Commission (CQC) (2015) reported that of the population of people with intellectual disabilities 3,230 were still hospital inpatients and of those about 1 in 5 people were more than $100 \mathrm{~km}$ from their homes.

\section{Discussion}

The local terminology in Norway and Sweden recognizes individual functional ability and environmental factors which are integral to the GAP relational model that 'contains three basic 
assumptions: disability arises from a disparity between the person and the environment; disability is situational or contextual; and disability is relative' (Goodley, cited in Carling Jenkins, 2014: 39). The terminology supports an holistic and contextual approach to working with users within the services discussed.

However, the English term of learning disability is described by the disability movement as oppressive, because it locates the causes of disability within the individual's condition rather than in the disabling social environment and does not support a contextual approach to working with users. A response has been to use the term learning difficulties as a non-oppressive term (Boxall, 2002).

A mixture of the modern models outlined by Carling Jenkins (2014) can be identified in England and to some extent in Norway and Sweden. Firstly, the economic model that positions people with disabilities as consumers with choice who hold resources can be clearly identified in England but has also been introduced in Sweden. All the countries are commodifying people with disabilities, as privatized disability services compete for profit and there are problems of poor quality services in England where privatization is far more extensive. A recommodification of a disabled persons labour has occurred with English work activation (Grover and Piggott, 2015), whereas in Norway and Sweden people with disabilities are not sanctioned if they do not enter paid work and have access to day activity centres. The British social model advocates for rights and particularly employment and the personalization of services (Grover and Piggott, 2015). However, it is in Sweden and Norway that people with disabilities have rights to personalized services, whereas in England people with intellectual disabilities are subject to eligibility under fair access to care (DH, 2002). Normalization and SRV theories had some policy influence in England (Race, 2007), but these models appear more influential in the Scandinavian countries.

\section{Welfare states and welfare benefits}

Welfare benefits that determine living standards are important for the achievement of Article 20 of the CRPD. The two Social Democratic welfare state regimes showed many similarities of a high state involvement and expenditure, both on benefits and on services, combined with high municipal state involvement in delivery of these services. As suggested by Esping-Andersen (1990), the level of services and benefits seem to indicate a high level of redistribution of wealth and a commitment to de-commodification.

Classified as a Liberal welfare state regime, England exhibits the traits suggested by EspingAndersen (1990), with the exposure of people with intellectual disabilities to work activation, recommodification and reduction in the value of benefits. The indications are that the privatized WCA assessments for ESA and PIP are reducing income, 'parking' or even removing income from people with intellectual disabilities through 'sanctions' (Woodin, 2015). Hence movements towards 'activation' and the conditionality of welfare benefits for people with disabilities are evident in England (Grover and Piggott, 2015), but in Norway and Sweden though activities are encouraged sanctions are not applied (Gubrium et al., 2014).

In the Scandinavian counties, income support is based on Frame Laws and rights and municipalities use discretion to meet needs though eligibility for disability benefits is more generous in Sweden. In Norway, $70 \%$ of income support staff are qualified, and it is usual to employ social workers for this work in both countries. In England, the central government DWP has privatized local work assessment and support which has meant that people with intellectual disabilities are not getting a 'professional' service informed by an understanding of intellectual disability (Heap, 
2015) This promotes an administrative focus on medical diagnoses in contrast to the more holistic approach to disability in the Scandinavian countries as something individual that varies over time and circumstance.

Comparing employment in England, $6.6 \%$ of people with intellectual disabilities were in some kind of paid employment (Emerson et al., 2013: 94) in Norway, 22\% participated in stateorganized job creation or employment and in Sweden some people with intellectual disabilities participate in employment through a special state-organized employment agency, but a majority of people with intellectual disabilities are outsiders of the labour market. However, these numbers from Norway do not show how many are in paid employment and earlier research indicates that this may be very few (Olsen, 2009)

From the estimates that were reported based on the country-specific measures, it appears that in all the three countries, people with intellectual disabilities had less income though more so in England where people with intellectual disability are also subject to income sanctions, a lowering of benefit levels and food banks. Wilkinson and Pickett (2010) demonstrate that both Sweden and Norway have a high degree of economic equality compared to England. Emerson and Parish (2010) have argued that poverty is a major issue for people with intellectual disabilities and that evidence shows that poverty exacerbates and causes further intellectual disability.

\section{Welfare states and social services}

The provision of social services are central to the achievement of Article 19 of the CRPD. The use of the social care welfare state typology (Antonnen and Sipila, 1996, cited in Munday, 2003) indicated that Norway and Sweden demonstrated the Scandinavian model in which social services are mainly provided and funded by the municipality. The means tested model applied to England, where the private or voluntary sector dominates provision and LA funding targets those most at risk (Race, 2007).

A similarity between the countries is that the local government has a central role, yet a difference is that people have rights to the provision of social care by the two Scandinavian countries, but in England this provision is highly selective, under FAC (DH, 2002, Race, 2007). However, FAC is also intended to reduce the differences in discretion between LAs, whereas variations between the Scandinavian municipalities remain problematic.

However, in England, there was a large increase of 81\% between 2008/2010 and 2010/2011 in people who have intellectual disabilities using personal budgets to empower and promote choice (Emerson et al., 2013: iv), and similarly in Sweden, the numbers accessing personal budgets has risen to 32,000 (Socialstyrelsen, 2009), whereas in Norway only $1 \%$ were reported to be using direct payments (Mork et al., 2014)

Residential status indicates the extent of community living and Sweden has legislated against hospital care (Race, 2007), but in England, a large number of people are still using hospital care (CQC, 2014). Adults with intellectual disabilities have no rights to supported housing in England and a large proportion of people in England still live with their families (Emerson et al., 2013: iii).

\section{Conclusion}

Through comparison and the identification of similarities and differences it has been demonstrated that in all the countries wider policy developments impact on services for people with intellectual disabilities, but these influences are mediated by the different welfare states and their institutions. 
Across all countries, a neo-liberal move to welfare markets and choice has influenced welfare provision (Peterson, 2011). For England, within both social services and income support the delivery of services has been opened up to the market. Likewise social care privatization though limited is growing in Norway and Sweden though there are important differences between them.

Similarly work activation policies have been introduced internationally and in the Scandinavian countries 'activities' and 'training' are acceptable outcomes for people with intellectual disabilities. For England, the outcome required is paid employment which has left people in a neglected or precarious situation and Grover and Piggott (2015) argue for the reintroduction of the right of people to retreat from the labour market.

The comparison suggests that institutional differences whereby the more autonomous Scandinavian municipality delivers both income support and social services with generally wellqualified staff enables a coherence of income support payments and social service needs in which policy aims can be consistently followed (Race, 2007). In contrast, the English services are fragmented between the central government DWP and its local agencies and the LAs and their private providers which may contribute to a fragmentation of purpose (Race, 2007) and the creation of a 'hidden majority' of large numbers of people with intellectual disability in England who do not receive any social service support in the community as they fall between the central government employment and local government social care institutions (Emerson et al., 2013: vi-vii). Moreover, the more autonomous Scandinavian municipalities are more powerful in both negotiating and implementing policies to benefit people with intellectual disabilities although Kananen (2014) claims this influence is diminishing.

It seems that although the policy goals are similar, the result, tempered by different national Welfare State regimes and institutions, differ to a large extent though policy ideas derived from the Liberal welfare states are spreading. An increased focus on the interplay between individual capability and environmental demands which can be seen as an important step forward for the rights of people with intellectual disability is seen in all three countries, yet the type of welfare state and institutions within which these rights are realized plays an important role.

\section{Declaration of Conflicting Interests}

The author(s) declared no potential conflicts of interest with respect to the research, authorship, and/or publication of this article.

\section{Funding}

The author(s) received no financial support for the research, authorship, and/or publication of this article.

\section{References}

General

American Association of Intellectual and Developmental Disabilities (AAIDD) (no date) Definition of intellectual disability. Available at: http://aaidd.org/intellectual-disability/definition\#.VOHP2p3F8eg (accessed 13 February 2015).

American Psychiatric Association (2013) Intellectual disability. Available at: http://www.dsm5.org/docu ments/intellectual\%20disability\%20fact\%20sheet.pdf (accessed 13 February 2015).

Carling-Jenkins R (2014) Disability and Social Movements: Learning from Australian Experience. Farnham: Ashgate. 
Carulla LS, Reed GM, Vaez-Azizi LM, et al. (2011) Intellectual developmental disorders: towards a new name, definition and framework for mental retardation/intellectual disability in ICD-11. World Psychiatry 10(3): $175-180$.

Cousins M (2005) European Welfare States: Comparative Perspectives. London: Sage.

Emerson E and Parish S (2010) Intellectual disability and poverty: Introduction to the special section. Journal of Intellectual and Developmental Disability 35(4): 221-223.

Emerson E, Hatton C, Robertson J, Roberts H, Baines S, Evison F and Glover G. (2013). People with Learning Disabilities in England 2011: Services and Supports. Lancaster: Improving Health and Lives: Learning Disabilities Observatory http://base-uk.org/sites/base-uk.org/files/knowledge/Employment\%20rates\%20in\% 20England\%20for\%20people\%20with\%20a\%20learning\%20disability/ihal2012-04pwld2 (accessed 22 July 2015).

Esping-Anderson G (1990) Three Worlds of Welfare Capitalism. Cambridge: Polity Press.

Esping-Andersen G (2014) Three worlds of welfare capitalism. In: Pierson C, Castles FG and Naumann I (eds) The Welfare State Reader. 3rd ed. Cambridge: Polity Press, pp. 136-150.

Flynn E (2011) From Rhetoric to Action: Implementing the UN Convention on the Rights of Persons with Disabilities. Cambridge: Cambridge University Press.

Grover C and Piggott L (2015) Disabled People, Work and Welfare. Is Employment Really the Answer. Bristol: Policy Press.

Kananen J (2014) The Nordic Welfare States in Three Eras from Emancipation to Discipline. Farnham: Ashgate.

Mackie T and Marsh D (1995) The Comparative Method. In: Marsh D and Stoker G (eds) Theory and Methods in Political Science. London: Macmillan Press Ltd, pp. 173-188.

Moreira A and Lodemel I (2014) Intoduction. In: Lodemel I and Moreira A (eds) Activation or Workfare? Governance and the Neo-liberal Convergence. Oxford: Oxford University Press, pp. 1-18.

Munday B (2003) European social services: a map of characteristics and trends. Available at: http:// www.coe.int/t/dg3/socialpolicies/socialrights/source/SocServEumap_en.doc. (accessed 15 March 2014).

Neuman WL (2006) Social Research Methods: Qualitative and Quantitative Approaches. 6th ed. Boston: Pearson Education Inc.

Peters BG (1998) The importance of comparison. In: Peters BG (ed) Comparative Politics: Theory Methods. London: MacMillan Press Ltd, pp. 1-27.

Peterson JH (2011) Marketisation and free choice in the provision of social services. Normative shifts 1982-2008. Social democrat lip service as a response to problems of legitimacy. In: Kettunen P and Petersen K (eds) Beyond Welfare State Models. Transnational Historical Perspectives on Social Policy. Cheltenham: Edward Elgar, pp. 170-198.

Power A, Lord JA and de Franco AS (2013) Active Citizenship and Disability. Implementing the Personalisation of Support. New York: Cambridge University Press.

Race D (2007) Intellectual Disability: Social Approaches. Maidenhead: Open University Press. McGraw-Hill Education.

Shakespeare T (2010) The social model of disability. In: Davis LJ (ed) The Disability Studies Reader. 3rd ed. Routledge: Abingdon, pp. 266-273.

Stafford A, Parton N, Vincent S, et al. (2012) Learning by comparing: some conceptual and methodological issues in conducting comparative research. In: Stafford A, Parton N, Vincent S, et al. (eds) Child Protection Systems in the United Kingdom: A Comparative Analysis. London: Jessica Kingsley, pp. 56-80.

Stoker G (1991) Introduction: trends in European local government. In: Batley R and Stoker G (eds) Local Government in Europe: Trends and Developments. Basingstoke: Macmillan Education Ltd, pp. 1-20.

Swain J, Finkelstein V, French S, et al. (eds) (1993) Disabling Barriers, Enabling Environments. London: OUP/Sage.

Ulmestig R (2013) Incapacity benefits -change and continuity in the Swedish welfare state. In: Lindsay C and Houston D (eds) Disability Benefits, Welfare Reform and Employment Policy. Basingstoke: Palgrave MacMillan, pp. 178-198. 
United Nations (UN) (2013) UN convention on the rights of persons with disabilities. Norway's initial report. Available at: $\mathrm{http}$ //tbinternet.ohchr.org/_layouts/treatybodyexternal/Download.aspx?symbolno=CRPD $\% 2 \mathrm{fC} \% 2 \mathrm{fNOR} \% 2 \mathrm{f} 1 \&$ (accessed 22 July 2015).

Wilkinson R and Pickett K (2010) The Spirit Level: Why Equality is Better for Everyone. London: Penguin. World Health Organisation (WHO) (1992) The ICD 10 Classification of Mental and Behavioural Disorders: Clinical Description and Diagnostic Guidelines. Geneva: WHO.

Yeates N (ed) (2008) Understanding Global Social Policy. Bristol: Policy Press.

Norway

Blåka S, Tjerbo T and Zeiner HH (2012) Kommunal Organisering 2012. Oslo: Norsk Institutt for By og Regionsforskning.

Brevik I (2012) Kjennetegn Ved Yngre Brukere av Heimebaserte Tjenester. Oslo: Norsk Institutt for By og Regionsforskning.

Brevik I and Høyland K (2007) Utviklingshemmedes Bo- og Tjenestesituasjon 10 Ar Etter HVPU-reformen. Oslo: Norsk Institutt for By og Regionsforskning / Stiftelsen for Industriell og Teknisk Forskning ved Norges teknisk-naturvitenskapelige universitet.

Epland J (2011) Økonomi og Levekair for Ulike Lavinntektsgrupper 2010. Oslo: Statistisk Sentralbyrå.

Gautun H, Bogen H and Grødem AS (2013) Konsekvenser av Konkurranseutsetting: Kvalitet, Effektivitet og Arbeidsvilkair i Sykehjem og Hjemmetjenester. Oslo: Fagbevegelsens senter for forskning, utredning og dokumentasjon.

Godager G, Iversen T and Hagen TP (2011) Omfang og Sammensetning av Omsorgstjenester i Tre Nordiske Land. Oslo: Health Economics Research Programme at the University of Oslo.

Gubrium E, Harslof I and Lodemel I (2014) Norwegian activation reform on a wave of wider welfare state change. In: Lodemel I and Moreira A (eds) Activation or Workfare? Governance \& the Neo-liberal Convergence. Oxford: Oxford University Press, pp. 19-46.

Hatland A (2010) Trygd og Arbeid. Oslo: Gyldendal akademisk.

Hedlund M (2009) Meningsbrytninger i Begrepet "Funksjonshemming”. Oslo: Universitetsforlaget.

Kuhnle S (2010) Velferdsstatens Politiske Grunnlag. Oslo: Gyldendal akademisk.

Kuhnle S and Kildal N (2005) The principle of universalism: tracing a key idea in the scandinavian welfare model. In: Standing G (ed) Promoting Income Security as a Right: Europe and North America. London: Anthem Press, pp. 303-326.

Manneråk S (2001) Fra Bruker Til Borger: En Strategi for Nedbygging av Funksjonshemmende Barrierer: Utredning Fra et Utvalg Oppnevnt ved Kongelig Resolusjon 21. April 1999: Avgitt til Sosial- og Helsedepartementet 29 Juni 2001. Oslo: Statens forvaltningstjeneste. Informasjonsforvaltning.

Mork E, Sundby B, Otnes B, et al. (2014) Pleie- og Omsorgstjenesten 2013: Statistikk om Tjenester og Tjenestemottakere. Oslo: Statistisk Sentralbyrå.

Norwegian Labour and Welfare Service (NAV) (2014) NAV som arbeidsgiver. Available at: https:// www.nav.no/no/NAV + og + samfunn/Om $+\mathrm{NAV} / \mathrm{Sok}+\mathrm{jobb}+\mathrm{i}+\mathrm{NAV} / \mathrm{NAV}+$ som + arbeidsgiver (accessed 15 September 2015).

Norwegian Labour and Welfare Service (NAV) (2015) Basic benefit. Available at: https://www.nav.no/en/ Home/Benefits+and+services/Relatert+informasjon/Basic+benefit.291751.cms (accessed 16 September 2015).

Norge Barne- og (2013) Frihet og Likeverd: Om Mennesker Med Utviklingshemming. Oslo: Regjeringen.

Norge Helse- og o (2006) Mestring, Muligheter og Mening: Framtidas Omsorgsutfordringer. Oslo: Departementenes servicesenter, Informasjonsforvaltning.

Norway Parliament (2009) Lov om Sosiale Tjenester i Arbeids- og Velferdsforvaltningen (sosialtjenesteloven). Oslo: Arbeids- og sosialdepartementet.

Norway Parliament (2011) Lov om Kommunale Helse- og Omsorgstjenester m.m. (helse- og omsorgstjenesteloven). Oslo: Helse- og omsorgsdepartementet. 
Næss A and Grue L (2012) Habilitering Som Koordinerende Tiltak: Erfaringer Fra Tre Brukergrupper. Oslo: Norsk institutt for forskning om oppvekst, velferd og aldring.

Olsen T (2009) Versjoner av Arbeid: Dagaktivitet og Arbeid Etter Avviklingen av Institusjonsomsorgen. Uppsala: Uppsala universitet.

Regjeringen (2014) Uførereformen iverksettes i 2015. Available at: https://www.regjeringen.no/nb/aktuelt/ Uforereformen-iverksettes-i-2015/id2005733/ (accessed 15 September 2015).

Söderström S and Tøssebro J (2011) Innfridde Mål Eller Brutte Visjoner?: Noen Hovedlinjer i Utviklingen Levekair og Tjenester for Utviklingshemmede. Trondheim: Norges teknisk-naturvitenskapelige universitet, Samfunnsforskning AS, Mangfold og inkludering.

Thomassen JS (1989) Fra Institusjon til Egen Bolig: Samspill om HVPU-reformen. Oslo: Kommuneforlaget. Tøssebro J (2010) Hva er Funksjonshemming. Oslo: Universitetsforl.

Tøssebro J and Lundeby H (2002) Statlig Reform og Kommunal Hverdag: Utviklingshemmetes Levekair 10 air Etter Reformen. Trondheim: Norges teknisk-naturvitenskapelige universitet, Institutt for sosialt arbeid og helsevitenskap.

Sweden

Blomqvist P (2004) The choice revolution: privatization of Swedish welfare services in the 1990s. Social Policy and Administration 38(2): 139-155.

Ericsson K (1999) Services in Sweden to persons with intellectual disabilities: a shift between two traditions of support. Presentation at a local policy conference in Charleroi. Available at: http://www.skinfaxe.se/ ebok/charle.pdf (11 May 2014).

Försäkringkassan (2013) Disability allowance. Faktablad: FK Handikappersättning/Disability Allowance_Fa (engelska). Försäkringkassan. Available at: https://www.forsakringskassan.se/wps/wcm/connect/2f8404a8645b-49fa-85d4-bc0f3929a861/Handikappers\%C3\%A4ttning-ENG.pdf?MOD=AJPERES (accessed 2 April 2014).

Försäkringkassan (no date) För dig som har en funktionsnedsättning. Available at: https://www.forsakrings kassan.se/wps/portal/privatpers/funktionsnedsattning (accessed 2 April 2014).

Granlund M (no date) Vad är utvecklingsstörning? Mälardalens Högskola. Available at: www.poms.nu/konf/ Mats_Granlund.pdf (accessed 2 May 2014).

Gruber J and Wise DA (2010) Social Security Programs and Retirement Around the World: The Relationship to Youth Employment, National Bureau of Economic Research Conference Report. Chicago: University of Chicago Press.

Gustafsson C, Öjehagen A, Hansson L, et al. (2006) Effekter av Psykosociala Insatser för Personer Med Utvecklingsstörning Och Samtidig Psykisk Ohälsa. En Sammanställning av Systematiska Översikter. Institutet För Utveckling av Metoder i Socialt Arbete. socialstyrelsen. Available at: http://www.social styrelsen.se/Lists/Artikelkatalog/Attachments/9520/2006-110-38_200611038.pdf (accessed 1 April 2015).

Jönsson L, Palme M and Svensson I (2010) Disability Insurance, Population Health and Employment in Sweden. Sweden: National Bureau of Economic Research project International Social Security.

Kananen J (2014) The Nordic Welfare State in Three Eras. From Emancipation to Discipline. Farnham: Ashgate.

Lindström I and Josephine N (2003) Swedish Elder Care. Stockholm: Svenska Kommunförbundet.

Mansell J, Beadle-Brown J and Clegg S (2004) The situation of large residential institutions in EuropeIn: Freyhoff G, Parker C, Coué M, et al. (eds) Included in Society: Results and Recommendations of the European Research Initiative on Community-based Residential Alternatives for Disabled People. Brussels: Inclusion Europe, pp. 28-56.

Ministry of Health and Social Affairs (2000) A National Action Plan for Disability Policy. Stockholm: Ministry of Health and Social Affairs.

Race D (2007) Intellectual Disability: Social Approaches. Maidenhead: Open University Press. McGraw-Hill Education.

Ratzka A (2003) Independent Living in Sweden. Independent Living Institute. Available at: http://www.in dependentliving.org/docs6/ratzka200302b.html (accessed 15 April 2014). 
Regeringskansliet (2011) En Strategi för Genomförande av Funktionshinderspolitiken 2011-2016. Bilaga till Protokoll vid Regeringssammanträde 2011-06-16 nr II:23. Stockholm. Regeringskansliet.

Skolverket (2011) What is the Compulsory School for Pupils With Learning Disabilities? Skolverket. Available at: http://www.skolverket.se/om-skolverket/andra-sprak-och-lattlast/in-english/the-swedisheducation-system/compulsory-school/for-pupils-with-learning-disabilities (accessed 15 September 2015).

Socialdepartementet (2001) Socialtjänstlag (2001:453). Stockholm: SFS.

Socialdepartementet (1993a) Lagen om Stöd Och Service Till Vissa Funktionshindrade. Lag (1993:387). Stockholm: SFS.

Socialdepartementet (1993b) Lagen om Assistansersättning. Lag (1993:389). Stockholm: SFS.

Socialstyrelsen (2009) Swedish disability policy - service and care for people with functional impairments. Artikelnummer 2009-126-188. Sweden: The National Board of Health and Welfare.

Socialstyrelsen (2006) A history of disability in Sweden. Sweden: The National Board of Health and Welfare. Artikelnummer 2006-114-12. Available at: http://en.misa.se/admin/UploadFile.aspx?path=/UserUploadFiles/ 200611413.pdf (accessed 2 May 2014).

Socialstyrelsen (2010) Inkomster och utgifter för vissa personer 20-64 air med funktionsnedsättningar Specialbearbetning av SCB: s undersökning HEK. Artikelnr 2010-1-12. Sweden: The National Board of Health and Welfare.

Socialstyrelsen (2011) Bostad med särskild service och daglig verksamhet. En forskningsöversikt. Artikelnr 2011-2-6. Sweden: The National Board of Health and Welfare.

Socialstyrelsen (no date) Frågor och svar om funktionsnedsättning och funktionshinder, användning av begreppen. Available at: http://www.socialstyrelsen.se/fragorochsvar/funktionsnedsattningochfunk tio\#anchor_2. (accessed 2 April 2015).

Statistik centralbyrån (2009) Hushaillens Ekonomi. Stockholm: SCB.

Stolt R, Blomqvist P and Winblad U (2011) Privatization of social services: quality differences in Swedish elderly care. Social Science and Medicine 72(4): 560-567.

Swedish Tax Agency (2012) Taxes in Sweden 2012: an English summary of tax statistical yearbook of Sweden. Available at: http://www.skatteverket.se/download/18.3684199413c956649b57c0a/13614426083 79/10413.pdf (accessed 3 April 2015).

Tideman M (2012) Current trends for people with intellectual disabilities in Sweden. Nordic Network on Disability Research (NNDR). Available at: http://nndr.no/current-trends-for-people-with-intellectual-dis abilities-in-sweden/ (accessed 2 June 2014).

Urban K and Åmark K (2001) Social rights and social security: the Swedish welfare state, 1900-2000. Scandinavian Journal of History 26(3): 157-176.

England

Alzubaidi H, Carr J, Councell R, et al. (2013) Average Income. An Analysis of the Income Distribution 1994/ 95- 2011/12. London: Department for Work and Pensions.

Beadle-Brown J, Mansell J, Cambridge P, et al. (2003) England. In European Intellectual Disability Research Network, Intellectual disability in Europe. Working Papers. Canterbury: Tizard Centre, University of Kent at Canterbury, pp. 100-120.

Beatty C, Fothergill S and Houston D (2013) The impact of the UK disability benefit reforms. In: Lindsay C and Houston D (eds) Disability Benefits, Welfare Reform and Employment Policy. Basingstoke: Palgrave Macmillan, pp. 134-152.

Blow E (2015) Learning Disability Policies and Issues-Commons library Standard Note SN/SP/07058. London: House of Commons Library. Available at: http:/www.parliament.uk/briefing-papers/SN07058/ learning-disability-policies-and-issues (accessed 20 February 2015).

Boxall K (2002) Individual and social models of disability and the experiences of people with learning disability. In: Race D (ed) Learning Disability: A Social Approach. London: Routledge, pp. 209-226. 
Clark T, Toynbee P, d'Ancona M, et al. (2015) Budget 2015: the verdict from our columnists. Available at: http://www.theguardian.com/commentisfree/2015/jul/08/budget-2015-verdict-writers-george-osborne (accessed 27 July 2015).

Cochrane A, Clarke J and Gewirtz S (2001) Comparing Welfare States. London: Open University.

Emerson E and Hatton C (2008) People with learning disabilities in England. CeDR ResearchReport. Available at: http://www.lancaster.ac.uk/staff/emersone/FASSWeb/Emerson_08_PWLDinEngland.pdf (accessed 21 July 2015).

Emerson E, Hatton C, Robertson J, et al. (2013) People with Learning Disabilities in England 2011: Services and Supports. Lancaster: Improving Health and Lives: Learning Disabilities Observatory. Available at: http://base-uk.org/sites/base-k.org/files/knowledge/Employment\%20rates\%20in\%20England\%20for\%20 people\%20with\%20a\%20learning\%20disability/ihal2012-04pwld2 (accessed 22 July 2015).

Griggs J, Hammond A and Walker R (2014) Activation for all. Welfare reform in the United Kingdom, 1995-2009. In: Lodemel I and Moreira A (eds) Activation or Workfare? Governance and the Neo-liberal Convergence. Oxford: Oxford University Press, pp. 73-100.

Grover C and Piggott L (2015) A right not to work and disabled people. In: Grover C and Piggott L (eds) Disabled People, Work and Welfare. Is Employment Really the Answer? Bristol: Policy Press, pp. 239-258.

Health and Social Care Information Centre (2015) Learning disability census-England 30th September 2014: Summary. Available at: http://www.hscic.gov.uk/article/2021/Website-Search?productid $=17233 \& q=$ Learning + Disabilities + Census + Report $++\&$ sort $=$ Relevance $\&$ size $=50 \&$ page $=1 \&$ area $=$ both $\#$ top (accessed 20 February 2015).

Heap D (2015) Disabled people, welfare reform and the balance of rights and responsibilities. In: Grover C and Piggott L (eds) Disabled People, Work and Welfare. Is Employment Really the Answer?. Bristol: Policy Press, pp. 87-104.

Jenkins R (1998) Culture, classification and (in)competence. In: Jenkins R (ed) Questions of competence, culture. classification and intellectual disability. Cambridge: Cambridge University Press, pp. 1-25

Karban K (2011) Social Work and Mental Health. Cambridge: Polity Press.

Kennedy S (2015) Independent Review of the Personal Independence Payment Assessment. Standard note SN07084.19.01.15 London: House of Commons Library. Available at: http://www.parliament.uk/brief ing-papers/SN07084/independent-review-of-the-personal-independence-payment-assessment (accessed 20 February 2015).

Mencap (2012a) Face the facts: stop the cuts. Available at: https://www.mencap.org.uk/sites/default/files/ documents/Face\%20the\%20facts_final_0.pdf (accessed 23 February 2015).

Mencap (2012b) Half a million people may lose benefit. Available at: https://www.mencap.org.uk/news/ article/half-million-disabled-people-may-lose-benefit (accessed 23 February 2015).

Mencap (2014a) Mencap calls for more changes to 'bedroom tax' Learning Disability Today. Available at: http://www.learningdisabilitytoday.co.uk/mencap_calls_for_more_changes_to_39bedroom_tax39_33 498.aspx (accessed 23 February 2015).

Mencap (2014b) Charities criticise government for personal independence payment decision delays. Available at: http://www.learningdisabilitytoday.co.uk/charities_criticise_government_for_personal_indepen dence_payment_decision_delays_25769808041.aspx (accessed 13 February 2015).

Peters B. G. (1998). The Importance of Comparison. In: Peters B.G. Comparative Politics: Theory Methods. London: MacMillan Press Ltd, pp. 1-27.

Peterson J. H. (2011). Marketisation and Free choice in the provision of social services. Normative shifts 1982-2008. Social Democrat lip service as a response to problems of legitimacy. In: Kettunen P and Petersen K (eds) Beyond welfare state models. Transnational Historical perspectives on social policy. Cheltenham: Edward Elgar, pp. 170-198.

Race D (2002) The historical context. In: Race D (ed) Learning Disability: A Social Approach. London: Routledge, pp. 23-52. 
Race D (2007) Intellectual Disability: Social Approaches. Maidenhead: Open University Press. McGraw-Hill Education.

Schwehr B (2014) What the Care Act 2014 means for the outsourcing of social work. Available at: http:// www.communitycare.co.uk/2014/03/14/care-act-2014-means-outsourcing-social-work/ (accessed 20 February 2015).

United Kingdom Department of Health (DH) (1959) Mental Health Act. London: HMSO.

United Kingdom Department of Health (DH) (1990) NHS and Community Care Act. London: HMSO.

United Kingdom Department of Health (DH) (1995) Disability Discrimination Act. London: HMSO.

United Kingdom Department of Health (DH) (1996) Community Care (Direct Payments)Act. London: HMSO.

United Kingdom Department of Health (DH) (1998) Modernising the Social Services (CM 4169). London: The Stationery Office.

United Kingdom Department of Health (DH) (2001) Valuing People: A New Strategy for Learning Disability for the 21st Century (CM5086). London: The Stationery Office.

United Kingdom Department of Health (DH) (2002) Fair Access to Care Services: Guidelines and Eligibility Criteria for Adult Services [LAC 2002(13)]. London: HMSO.

United Kingdom Department of Health (DH) (2007) Valuing People Now. London: HMSO.

United Kingdom. Department of Health (2012) Transforming care: A national response to Winterbourne View hospital. Department of Health Review and Final Report. Available at: https:/www.gov.uk/gov ernment/uploads/system/uploads/attachment_data/file/213215/final-report.pdf (accessed 20 July 2015).

United Kingdom Department of Health (DH) (2014) Care Bill. London: HMSO.

United Kingdom Department of Health and Social Security (1971) Better Services for the Mentally Handicapped. London: HMSO.

United Kingdom Parliament (2010) Equality Act. London: HMSO.

United Kingdom Department of Work and Pensions (2012) Welfare Reform Act. London: HMSO.

Williams P (2002) Residential and day care services for adults. In: Race D (ed) Learning Disability: A Social Approach. London: Routledge, pp. 53-67.

Williams V (2013) Learning Disability Policy and Practice. Changing Lives? Basingstoke: Palgrave Macmillan.

Woodin S (2015) Supply- and demand-side policies and the employment of learning disabled people in Britain. In: Grover C and Piggott L (eds) Disabled People, Work and Welfare. Is Employment Really the Answer?. Bristol: Policy Press, pp. 181-198.

Wright S (2011) Steering with sticks, rowing for rewards: the new governance of activation in the UK. In: van Berkel R, de Graaf W and Sirovatka T (eds) The Governance of Active Welfare States in Europe. Basingstoke: Palgrave Macmillan, pp. 85-109. 